\title{
Cooperative Banks in Greece and Small \& Medium Enterprises Views at a Time of Credit Constraints
}

\author{
John Mylonakis \\ Bank Marketing Researcher, Greece \\ E-mail: imylon@otenet.gr
}

Received: Sep. 24, 2020 Accepted: Oct. 25, $2020 \quad$ Published: Nov. 15, 2020

doi:10.5296/ifb.v7i2.17943 URL: http://dx.doi.org/10.5296/ifb.v7i2.17943

\begin{abstract}
Cooperative banks are among those credit institutions that have played an important role in the financial systems of many countries, usually operating supplementary to the traditional commercial banks, mainly at regional level and aiming mostly at supporting SMEs financial needs. They provide traditional banking products to local SMEs even in remote areas. The number of Cooperative Banks in Greece has been decreased from originally 16 banks to 6 in the second half of 2020. The scope of this paper is to examine the managers' views of 158 SMEs towards Cooperative Banks' support (banking facilities) over the economic and financial crisis period (2015-2019). The research was carried out the last three months of 2019, using constructed questionnaire to a random sample of 208 Cooperative Banks' clientele in places where Cooperative Banks have branches. Research showed that SMEs have a quite good opinion for Cooperative Banks presence in Greece.
\end{abstract}

Keywords: cooperative banking, financial services 


\section{Introduction}

The banking sector incorporates a variety of institutions with diverse business models and ownership structures. Public, state, savings, co-operative, mutual and private banks may co-exist in the same diversified market. Cooperative banks are among those credit institutions that have played an important role in the financial systems of many countries and more precisely in Europe (Forteyne, 2007). They are deemed as significant institutions for deposits and major sources of credit for households and Small and Medium firms (SMEs). Traditionally, SMEs are considered as the backbone in many countries in Europe, contributing to job creation and economic growth (Lang et al., 2016).

The institutional structure, legal and regulatory status, products, and business models varies across countries and geographical regions (Cuevas \& Buchenau, 2018; Cuevas \& Fischer, 2006). In practice, Cooperative Banks appear to operate supplementary to the traditional commercial banking system, mainly at regional level and aiming mostly in supporting SMEs financial needs. Cooperative banks are, many times, viewed as old-fashioned and ineffective financial institutions (Bülbül et al., 2013). Other studies support the view that cooperative banks could be entrepreneurial, cost-effective, efficient, and business-like organizations (Rabobank, 2009). Today, Cooperative Banks in Europe have 51,500 contact outlets and employ approximately 713,000 people in Europe (EACB, 2020).

Cooperative banks were viewed as institutions owned by their members who are, also, customers of the bank with equal voting power and aim, not exclusively, at profit business maximization. In practice, much diversity existed in actual business models. Today, Cooperative banks differ in size, organizational structures, membership policy, and non-core activities. Recently, in the aftermath of financial deregulations processes, liberalization and privatization movements the role and the institutional forms of Cooperative banks changed in almost all European countries. Throughout the economic and financial crisis Cooperative Banks in Europe increased their number of customers and financial services (Oliver Wyman, 2014).

\section{Cooperative Banking in Greece}

The main goals of Cooperative Banks in Greece have been to provide credit and savings opportunities to local communities not well served by Commercial Banks (Papadimitriou \& Toay, 2014). The number of Cooperative Banks in Greece has been decreased from originally 16 banks to 6 in the second half of 2020. They operate 62 branches with 527 employees, corresponding to $2.9 \%$ of the employees of the four systemic commercial banks. Their deposits correspond to $1.7 \%$ (2.6 billion $€$ ) of the four systemic banks and their assets to $1.2 \%$ (3.2 billion $€$ ). In places they are physically established and operate their local market share is about $20 \%$ while their portfolio represents loans to SMEs by $85 \%$. In addition, two small Credit Cooperatives (Aitoloakarnanias, Voiotias) complete the Cooperative Banking spectrum in Greece.

Since August 2020, the biggest Cooperative Bank (Pankritia) left the cooperative banking and moved to the club of conventional Commercial Banks. The Pankritia Cooperative Bank had 
almost $51 \%$ of the total deposits and $54 \%$ of loans of total Cooperative Banks. The current 6 Cooperative Banks, their number of their branches and number of staff are as following (Hellenic Bank Association, 2020).

Table 1.

\begin{tabular}{lll}
\hline Cooperative Banks & No of branches & No of employees \\
\hline Cooperative Bank of Chania & 33 & 222 \\
Cooperative Bank of Thessaly & 10 & 85 \\
Cooperative Bank of Epirus & 9 & 84 \\
$\begin{array}{l}\text { Cooperative Bank of Central } \\
\text { Macedonia }\end{array}$ & 3 & 48 \\
Cooperative Bank of Karditsa & 4 & 38 \\
Cooperative Bank of Drama & 3 & 50 \\
\hline
\end{tabular}

In 2020, the biggest Cooperative Bank is the Cooperative Bank of Chania sharing, respectively, almost $22 \%$ of deposits and $17 \%$ of loans of the total Cooperative Banks.

The Cooperative Banks in Greece and the Credit Cooperatives established, on 22-7-1995, the Association of Cooperative Banks of Greece (ESTE) which represents their members in the European Association of Cooperative Banks (EACB) and the International Cooperative Banking Association (ICBA).

Cooperative banks activities are mainly based on principles of cooperation, targeting mainly Small and Medium-sized enterprises (which may not have easy access to traditional banks) and individuals with products adapted to local conditions and needs, at lower cost. Therefore, they considered to strengthen key sectors of the Greek economy such as tourism, manufacturing, and agricultural production.

The close connection of Cooperative Banks with the local economy and society provides them with special advantages, such as better knowledge of the local market distortions and customers' special needs, financial conditions and business prospects, in order to meet better their customers' needs. Cooperative Banks operate without the commitments and obligations of large commercial banks and are governed by softer regulations which give them significant comparative advantages over the wider banking system. 


\section{Research Methodology}

The scope of this short paper is to examine the SMEs managers' views towards Cooperative Banks' support and banking facilities over the economic and financial crisis period from 2015 to 2019. The research was carried out the last three months of 2019, using constructed questionnaire to a random sample of 208 Cooperative Banks clientele, in 8 large Prefectures where Cooperative Banks have branches. The response rate was, surprisingly, $76 \%$ or 158 returned completed questionnaires.

Table 2.

\begin{tabular}{lll}
\hline Prefectures & Frequency & Percent \\
\hline IRAKLIO - CRETE & 28 & 17.72 \\
CHANIA - CRETE & 26 & 16.45 \\
TRIKALA - THESSALY & 23 & 14.56 \\
IOANNINA - EPIRUS & 19 & 12.02 \\
DRAMA - THRACE & 18 & 11.39 \\
LASITHI - CRETE & 17 & 10.76 \\
THESSLONIKI MACEDONIA & 16 & 10.13 \\
ATTICA & 11 & 6.97 \\
Total & 158 & 100.00 \\
\hline
\end{tabular}

The questionnaire consisted of 22 closed-ended questions which were divided into four main parts.

1) The first part includes questions concerning the profile of the SME, like its legal form, size, sector in which it operates, as well as the prefecture of its registered office.

2) The second part comprises questions that reflect the views of SMEs managers, regarding the financial problems faced by SMEs during the crisis, the cooperating banks attitudes, and their overall banking relationship with their Cooperative Bank.

3) The third part is more concrete focusing on the Cooperative Banks' lending support to SMEs, like easy access, type of finance and total loans provided. 
4) The fourth part includes questions regarding the views of SMEs on Cooperative Banks attitudes, like business support, the implementation of debt restructuring programs, as well as entrepreneurship.

The research is neither Business-to-Business survey nor corporate behavior-style analysis or exhaustive general Cooperative Banking examination. It was an attempt to gather and present information from SMEs manager, using simple descriptive analysis, on a rather neglected area of Cooperative Banking. Local practices, customs and preferences differentiate managers' attitudes from other kinds of business behaviors; political interventions are commonplace in small local societies.

\section{Research Results}

Research results showed that the legal form of the majority of SMEs collaborating with Cooperative Banks is Limited Companies (47\%), Sole proprietorship (32\%, one-man companies) and Limited partnership (21\%). The responded SMEs are either small companies or quite small companies employing less than 50 or 15 people respectively with annual turnover between 1 to 10 million $€$. They engage in the secondary sector by $42 \%$ (small production industries), in tourism (41\%) and in agriculture (17\%).

The crucial problems SMEs face is taxation (44\%), working capital constraints (29\%), market structure distortions (14\%) and difficulties in banking access (13\%). Apart from close banking relationships SMEs keep with the 6 Cooperative Banks, many SMEs are also good clients of the 4 systemic commercial banks.

SMEs easy funding is viewed as a particularly important factor which Cooperative Banks have competitive advantage. Bank loans are mainly used to face working capital needs $(75 \%)$, liquidity shortages (15\%) and temporary financial needs (10\%). Loans applied vary from up to $50.000 €(37 \%)$, from 50.000 to $250.000 €(55 \%)$ and from 250.000 to $450.000 €(8 \%)$. Many SMEs (75\%) replied that their borrowing has been increased over the last 5 years and that it has significantly contributed to the annual company's turnover increase. They, also, much appreciate the fact that the total borrowing costs have remained unchanged.

Regarding the Cooperative Banks' contribution to SMEs growth and entrepreneurship, many of the SMEs show very positive opinion $(22 \%)$, quite positive $(64 \%)$, low positive $(9 \%)$ and no impact (5\%). Almost the same views share SMEs on the question regarding Cooperative Banks' contribution to assist them in keeping their market position (sustainability) through restructuring programs, mainly debts refinancing facilities. The majority of the SMEs show positive views (57\%) for Cooperative Banks market presence, very positive (15\%), less than positive $(15 \%)$ and negative view (11\%). The same attitude appears regarding the friendliness factor of Cooperative Banks towards SMEs. Many SMEs believe that Cooperative Banks approach them very friendly (54), quite friendly (36\%) and not friendly (10\%). Thus, in general, SMEs show having a quite good opinion for Cooperative Banks presence in Greece.

\section{Conclusions}

The scope of this short paper was to record the views of the SMEs managers towards 
Cooperative Banks' overall support and banking facilities over the economic and financial crisis period under capital constraints policies (2015-2019). SMEs are mostly governed by one person or by a strict managerial team close to the owner(s). Thus, their views concerning the contribution of Cooperatives Banks in the everyday entrepreneurial life are considered significant and must be appreciated.

The crucial problems SMEs face is taxation, working capital needs, market structure distortions and difficulties in approaching Cooperative Banks. The last seem to be more client oriented and avoid the usual old fashion policy of simply waiting for receiving loan applications. This is one the reasons that SMEs are simultaneously good clients of the 4 systemic commercial banks which are more customer oriented, offering concrete banking products on tourism, agriculture and for small industrial units.

Working capital facilities, liquidity shortages and temporal financial assistance are the main requirements of SMEs that Cooperative Banks must examine ways to satisfy their needs and thus strengthen their market share. Cooperative Banks must, also, exploit the fact that many SMEs have strong positive views for their contribution to business life and consider their presence as significant to entrepreneurship.

The survey is not an exhaustive research of traditional business or customer marketing satisfaction but rather a first attempt to examine SMEs managers' views towards Cooperative Banks, a rather neglected research area, if any research done. Thus, further research is needed using conventional research techniques that need time and, in many ways, not affordable costs.

\section{References}

Bülbül, D., Schmidt, R. H., \& Schüwer, U. (2013). Savings banks and cooperative banks in Europe. SAFE Policy White Papers, No 5.

Cuevas, C. E., \& Buchenau, J. (2018). Financial cooperatives: Issues in regulation, supervision and institutional strengthening. World Bank: Washington, DC. https://doi.org/10.1596/30916

Cuevas, C. E., \& Fischer, K. P. (2006). Cooperative financial institutions: Issues in governance, regulation, and supervision. World Bank Working Paper number 82. https://doi.org/10.1596/978-0-8213-6684-4

EACB. (2020). Retrieved from http://www.eacb.coop/en/co-operative-banks.html

European Association of Co-operative Banks. (2013). In collaboration with Tilburg University, The Netherlands, to commemorate the 200th birthday of Friedrich Wilhelm Raiffeisen (1818-1888) (Prof. Dr. Hans Groeneveld Ed., p. 6).

Forteyne, W. (2007). Cooperative Banks in Europe-Policy Issues. IMF Paper WP/07/159. https://doi.org/10.5089/9781451867237.001

Hellenic Banks Association. (2020). Retrieved from https://www.hba.gr/Hebic/UplPDFs/2020BGR/3e.pdf 
http://www.eif.org/news_centre/publications/EIF_Working_Paper_2016_36.htm

Lang, F., Signore, S., \& Gvetadze, S. (2016). The role of cooperative banks and smaller institutions for the financing of SMEs and small midcaps in Europe. EIF Working Paper, No. 2016/36, European Investment Fund (EIF), Luxembourg.

Oliver, W. (2014). Cooperative Banking_Leveraging the Cooperative Difference to adapt to a new environment. Financial Services.

Papadimitriou, D., \& Toay T. (2014). Co-operative Banking in Greece: A proposal for rural reinvestment and urban entrepreneurship. Levy Economics Institute of Bard College. Annandale-on-Hudson, New York.

Rabobank Group. (2009). Co-operative banks in the new financial system.

\section{Copyright Disclaimer}

Copyright for this article is retained by the author(s), with first publication rights granted to the journal.

This is an open-access article distributed under the terms and conditions of the Creative Commons Attribution license (http://creativecommons.org/licenses/by/4.0/). 